\title{
1. The challenge of reforming bicameralism
}

\section{Richard Albert, Antonia Baraggia and Cristina Fasone}

\section{BICAMERALISM UNDER PRESSURE}

Bicameralism is under pressure in every corner of the world. ${ }^{1}$ From North to South America, from Australia to Africa, and from Asia to Europe, there are some signs of success, yet perhaps more of failure, in efforts to reform bicameralism to respond to the modern expectations of democracy.

The second legislative chamber-however we choose to label it, whether the upper house, the senate, or the council of states-has long been at the periphery of constitutional discourse. Consider only that scholars have historically used the terms 'legislature' and 'lower house' synonymously, ${ }^{2}$ reflecting the comparative irrelevance of the other body. More recently, however, the scholarly bias in favor of lower houses has been rapidly diminishing. Scholars are increasingly studying the second chamber, recognizing that ignoring it in their work misses an important, often even decisive, aspect of the legislative process and of the fulfillment of parliamentary functions. ${ }^{3}$ This makes the focus of this volume - 'bicameralism under pressure' - particularly timely.

1 See generally Betty Drexhage, Bicameral Legislatures (Linguist Link Europe 2015) 37-61.

2 See Philip Norton, 'Adding Value? The Role of Second Chambers' (2007) 15(1) Asia Pacific L. Rev. 3, 3, noting the synonymous use of the terms 'legislature' and 'lower house'.

3 See generally John Coakley, 'The Strange Revival of Bicameralism' (2014) 20 J. Legis. Stud. 542, 542-3; John Uhr, 'Bicameralism', in R.A.W. Rhodes, Sarah A. Binder and Bert A. Rockman (eds), The Oxford Handbook of Political Institutions (OUP 2006) 474; and the collective volume edited by Jörg Luther, Paolo Passaglia and Rolando Tarchi, A World of Second Chambers. Handbook for Constitutional Studies on Bicameralism (Giuffrè 2006), in particular, Jörg Luther, 'The Search for a Constitutional Geography and Historiography of Second Chambers', 3. 
The pressure that this collection aims to explore comes precisely from the difficulty to reform bicameralism, whose legal framework is normally entrenched under rigid rules of constitutional change. This raises a serious problem where second chambers are perceived as unsatisfactorily performing their role. ${ }^{4}$ Hence, in most countries a change in the composition, functions and powers of the second chamber would require a constitutional amendment. The likelihood of successful reform on bicameralism is accordingly inversely proportional to the degree of change sought. Consider that efforts to formally amend the Senate of Canada have failed dramatically, not only because of the complicated structure of escalating amendment rules in the Constitution but equally because of the nature of the proposed changes themselves. ${ }^{5}$ It is not by chance that the governing party managed to change the system of appointment to the Senate only with recourse to non-constitutional procedures, specifically through executive command. ${ }^{6}$

Besides constitutional rigidity, another factor affecting the difficulty of reforming second chambers is the inevitable fallout of these changes on other parts of the Constitution. ${ }^{7}$ There is also a strong status quo bias on the part of the public and of political parties and of course senators themselves, who might be disempowered in the case of successful reform. What makes reform even more difficult is that senators ordinarily have a vote on any amendment

4 Anthony Mughan and Samuel C. Patterson, 'Senates: A Comparative Perspective', in S.C. Patterson and A. Mughan (eds), Senates: Bicameralism in the Contemporary World (Ohio State University Press, 1999) 333, 338.

5 Richard Albert, 'The Difficulty of Constitutional Amendment in Canada' (2015) 53(1) Alberta Law Review 85, 93-96; and Richard Albert, 'Constitutional Amendment by Stealth' (2015) 60(4) McGill L.J. 673. The interpretation of the Canadian Constitution on the appropriate constitutional amendment procedure to apply to reform the Senate has been a matter of controversy eventually solved by the Supreme Court of Canada in Reference re Senate Reform, 2014 SCC 32, [2014] 1 SCR 704 ('Senate Reference').

${ }^{6}$ See Meg Russell, 'The failed Senate reform in Italy: international lessons on why bicameral reforms so often (but not quite always) fail', The Constitution Unit Blog, 20 July 2018, https://constitution-unit.com/2018/07/20/the-failed-senate-reform-in-italy -international-lessons-on-why-bicameral-reforms-so-often-but-not-quite-always-fail/ (accessed 20 November 2018).

7 See, in detail, Meg Russell and Mark Sandford, 'Why are Second Chambers so Difficult to Reform?' (2002) 8(3) J. Legisl. Stud. 79, 83-87. Indeed, only constitutional entrenchment of second chambers' framework provisions could not explain why, in the UK, an overall reform of the House of Lords in the twentieth and twenty-first centuries has not succeeded after decades of debates in addition to the removal of most hereditary peers: see Meg Russell, The Contemporary House of Lords: Westminster Bicameralism Revived (OUP 2013) 27-37. 
to their chamber. There is another point: the incumbent government may be unwilling to give its blessing to reform when its party controls the upper house.

Perhaps the most important theoretical question raised by second chambers is how to define their role and function. Scholars have offered many explanations. These include representation, federalism, deliberation, executive accountability, and continuity in governance. ${ }^{8}$ Metaphors of sobriety and drunkenness abound. Whereas the inebriated lower house engages in public debate in an atmosphere of fervor and excitement, the upper house moderates its discourse with cool-headed deliberation. ${ }^{9}$ Most of these justifications fit within broadly-conceived notions of representation and reflection. ${ }^{10}$ We know that a second chamber may fulfill both of these principles concurrently-for instance, situations in which the chamber both represents territorial interests and compels further legislative deliberation based on those interests. However, it is not difficult to think of situations in which these justifications for bicameralism are in direct conflict. For example, an upper chamber representing territorial interests may choose to perform an obstructive role, like the German Bundesrat especially before the constitutional reform of 2006. This role may be understood as perfectly consistent with its representative function, but it would undermine the chamber's reflective aspirations.

Many scholars whose work is assembled in this volume have recognized this very tension. In her chapter, Maria Romaniello argues that recent decades have seen a considerable shift from the élite, reflective model of upper chambers to the territorial, representative model. This has placed the concept of representation at the center of the discourse on bicameralism. However, this shift has not precipitated changes to our taxonomy of bicameralism. The continuing imagery of the upper house as the 'house of elders' is a good example. ${ }^{11}$ Labeling is of course not conclusive of meaning. But insofar as labeling matters, we should begin to ask whether these and other historical labels are consistent with how we understand bicameralism today. Following this shift from reflective to representative functions, it was assumed that bicameralism would remain within the exclusive domain of federal systems. But the numbers

8 Nicholas Aroney, 'Four Reasons for an Upper House' (2008) 29 Adelaide L. Rev. 205, 205-209; and Meg Russell, 'What Are Second Chambers For?' (2001) 54 Parl. Aff. 442, 443-453.

9 Jeremy Waldron, 'Bicameralism and the Separation of Powers' (2012) 65 Current Legal Probs. 31, 38.

10 Norton (n 2) 6-8.

11 See David E. Guinn, Bicameral Development: Second Houses in Developmental Perspective (26 June 2014) (unpublished manuscript) 9, 12. 
have challenged this hypothesis. ${ }^{12}$ In the second half of the twentieth century, bicameral legislatures were on the decline. ${ }^{13}$ But the turn of the century has witnessed an overall resurgence of bicameral legislatures. ${ }^{14}$

John Coakley has found that the proportion of unitary states with unicameral legislatures has increased, while the proportion of federal states with bicameral legislatures has slightly decreased. ${ }^{15}$ Whereas 82 per cent of federal states in his sample of study had bicameral legislatures in 1996, 76 per cent had bicameral legislatures in $2014 .{ }^{16}$ Over the same period, the proportion of bicameral legislatures in unitary (and regional) states increased from 26 to 35 per cent. ${ }^{17}$ Therefore, if as a matter of empirical reality over a third of unitary states have bicameral legislatures, it would be far too simplistic to define bicameralism as a purely federal phenomenon. As we discuss further below, the Italian experience may offer useful insights into the rise of bicameralism in unitary or regional states.

The good news for scholars interested in bicameralism is that significant questions still remain undertheorized or unanswered. We are still far from resolving definitional questions about what we mean by a bicameral parliament. For example, should the self-conscious identification of a system as unicameral or bicameral affect our analysis? Is it fair to treat the European Union as a unicameral system, simply because it has one 'parliament', even though the Council of Ministers performs a significant legislative role? ${ }^{18}$ Further, if we were to accept Jeremy Waldron's 'anti-perfection' thesis about different systems of representation complementing one another, ${ }^{19}$ why should we continue to restrict ourselves to the binary of either one or two assemblies? Why not pursue the tricameral model based on Confucian constitutionalism ${ }^{20}$

12 Note also empirical analyses on the capacity of upper houses to effectively represent territorial interests: see Meg Russell, 'The Territorial Role of Second Chambers' (2001) 7(1) J. Legis. Stud. 105, 113-115 and Francesco Palermo, 'Beyond Second Chambers: Alternative Representation of Territorial Interests and Their Reasons' (2018) 10(2) Perspectives on Federalism 50.

13 See Louis Massicotte, 'Legislative Unicameralism: A Global Survey and a Few Case Studies' (2001) 7(1) J. Legis. Stud. 151, who discusses the historic rise of unicameralism, and the decline of bicameralism.

14 See generally Coakley (n 3).

15 Id. at 548 .

16 Id. at 550.

17 Id.

18 Sergio Fabbrini, 'The European Union and the Puzzle of Parliamentary Government' (2015) 37(5) J. Eur. Integr. 571, 576; and Robert Schütze, An Introduction to European Law (CUP 2012) 9-27.

19 Waldron (n 9) 35.

20 See Jiang Qing, 'The Way of the Humane Authority: The Theoretical Basis for Confucian Constitutionalism and a Tricameral Parliament', in Daniel A. Bell and 
or Sweden's quad-cameral model ${ }^{21}$ It is not obvious why considerations of efficiency and cost should constrain us to stop at the magic number 'two'. We would suggest that neither prescription nor antiquity can offer a complete answer to these questions.

\section{BICAMERALISM AND 'CONSTITUTIONAL CHANGE' IN INDIA AND ITALY}

Bicameralism is undergoing interesting changes around the world. Take India and Italy, for example: in one case, the attempts to change bicameralism were formal, and in the other, such attempts were informal.

The history and constitutional design of bicameralism in Italy is fascinating. The nature and composition of the legislature was a subject of significant contestation during the constitution-making process. ${ }^{22}$ Those arguing in favor of a bicameral legislature eventually succeeded, but not without making several concessions to the pro-unicameralists. Both houses would be elected directly by the citizens, based on universal adult suffrage. ${ }^{23}$ There were only relatively minor differences between the Senate and the Chamber of Deputies. These differences concerned the length of terms, the voting system, age requirements, and similar matters. ${ }^{24}$ Some of the differences between the two Houses were further diluted in the early years of constitutional experience, when the Senate's term was rendered effectively equivalent to the term of the Chamber of Deputies. ${ }^{25}$ Early constitutional scholars such as Constantino Mortati, who was the first signatory of the motion passed by the Constituent Assembly on 7 September 1946 supporting the creation of a second chamber, were skeptical about how bicameralism had been designed. ${ }^{26}$ Mortati cautioned against the

Ruiping Fan (eds), A Confucian Constitutional Order: How China's Ancient Past Can Shape Its Political Future (Princeton University Press 2013) 27, discussing a tricameral system.

${ }_{21}$ See Drexhage (n 1) 7, mentioning Sweden's 'four chambers'.

22 See Mario Einaudi, 'The Constitution of the Italian Republic' (1948) 42(4) Am. Pol. Sci. Rev. 661, 665-667 discussing the political climate in which the Constitution was written. In Italian, amongst many, see Gianni Ferrara, 'Art. 55', in G. Branca (ed), Commentario della Costituzione. Art. 55-63. Le Camere, vol. I (Zanichelli 1984) 5; Enzo Cheli, 'Bicameralismo', in Digesto delle discipline pubblicistiche, vol. II (UTET 1987) 318-325; Livio Paladin, 'Bicameralismo', in Enciclopedia giuridica, vol. V (Treccani 1988) 3; and Lorenza Carlassare, 'Un bicameralismo discutibile', in L. Violante (ed), Storia d'Italia. Annali 17. Il Parlamento (Giappichelli 2001) 325.

23 Costituzione [Cost.] (It.) (1947), art. 60.

24 Id., arts 55-57.

25 Costituzione [Cost.] (It.) (1963, Const. Law no. 2), art. 60.

26 See Lorenza Violini, 'The Reform of Italian Bicameralism: Current Issues' (2014) 6(1) Italian J. Pub. L. 33, 34. 
possibility of unnecessary duplication, noting that the arrangement of political parties, as displayed since 1953, did not require a second chamber. This seemed to echo at least the first half of Abbé Sieyès' objection to bicameralism — with which Jeremy Bentham also concurred: that if a second chamber agreed with the first, it was in fact 'useless'. ${ }^{27}$

As Pietro Faraguna argues in his chapter in this volume, an increasing need was felt to 'reconnect the different layers of the European composite Constitution', through the recognition of territorial interests in the Italian Senate. The constitutional reform bill, which was passed by the Parliament but later failed in a referendum on 4 December 2016, addresses some of these issues. ${ }^{28}$ The proposed reform tried to move away from what is often described as 'perfect or asymmetric bicameralism' to a system in which the confidence relationship between the Senate and the government would be abolished, and in which the Senate would represent regional and local interests.

In terms of constitutional design, the Indian system of bicameralism is closer to what we might understand as 'tempered asymmetric bicameralism' . ${ }^{29}$ The Indian Parliament consists of the Lok Sabha (Lower House) and Rajya Sabha (Upper House). ${ }^{30}$ While the Lok Sabha is directly elected and dissolves with the calling of an election, ${ }^{31}$ the Rajya Sabha is indirectly elected by state assemblies and cannot be dissolved. ${ }^{32}$ Elections to the Rajya Sabha are staggered, with a third of its body coming up for election every two years. In general, the Rajya Sabha is a co-equal house with a veto power over legislation. Nevertheless, since the Lok Sabha is more than twice the size of the Rajya Sabha, it may convene a joint session of Parliament in order to enact legislation that fails to secure majority approval in the Rajya Sabha. ${ }^{33}$ The Rajya Sabha's

27 The phrase continues: 'if not, it is bad'. See George Tsebelis and Jeannette Money, Bicameralism (CUP 1997) 35, quoting Sieyès. See also the letter sent by Jeremy Bentham to his Fellow-Citizens of France, on Houses of Peers and Senates (1830), III § 8, https://archive.org/stream/jeremybenthamtoh00bent/jeremybenthamtoh00bent_djvu .txt (accessed 20 November 2018); and Lewis Rockow, 'Bentham on the Theory of Second Chambers' (1928) 22(3) American Pol. Sc. Rev. 576.

${ }_{28}$ Bernardo Giorgio Mattarella, 'The Ongoing Constitutional and Administrative Reforms in Italy' (2016) 2 Riv. Trim. Dir. Pubbl. 427.

29 Domenico Amirante, India (Il Mulino 2007) 88 (own translation from Italian of 'bicameralismo asimmetrico temperato').

30 See Constitution of India, art. 79 (the Lok Sabha is referred to as the 'House of the People'; the Rajya Sabha is referred to as the 'Council of States').

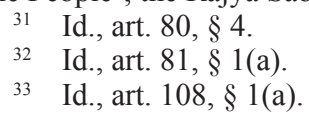


powers are also far more limited than those of the Lok Sabha in the case of 'money bills'. 34

In design terms, these arrangements would have been expected to promote the assertion of regional interests in national decision-making processes. However, in the first few decades of constitutional experience, the Rajya Sabha did not perform its anticipated role as a funnel for regional interests. Under the leadership of the Nehru-Gandhi family, the Congress Party secured decisive electoral victories in the federal parliament and the state assemblies. ${ }^{35}$ A few years into the functioning of the Constitution, the Rajya Sabha was thus described as amongst the 'weakest second chambers in the world' ${ }^{36}$ Instead of airing regional aspirations and grievances, the Rajya Sabha was looked upon as a 'house of patronage', ${ }^{37}$ occupied by party candidates who were unable to secure positions in the Lok Sabha.

Matters changed considerably with the decline of the Congress Party and the rise of regional political parties. Between 1989 and 2014, no single party was able to secure a majority of seats in the Lok Sabha, and this required rule by coalition governments. ${ }^{38}$ These coalitions often consisted of eight or more parties. Similarly, state assemblies were no longer dominated by a single party or group of parties. This dramatically altered the political relevance and functions of the Rajya Sabha. No example better demonstrates this revised role than the victory of the Narendra Modi-led Bhartiya Janata Party (BJP) in the national elections of 2014. ${ }^{39}$ Although the BJP became the first to secure an absolute majority of seats in the Lok Sabha in a quarter of a century, the party still controls fewer than 50 seats in the Rajya Sabha (and fewer than 70 seats including its alliance partners).$^{40}$ This places it well short of the 123 -seat majority mark in the Rajya Sabha, leaving it with no choice but to build consensus in support of its legislative proposals. The staggered election process for the Rajya Sabha indicates that even if the BJP were to gain decisive state election mandates, it would take a while for it to reach the majority mark. Joint sessions expend considerable political capital and have proven difficult to convene, suggesting that an approach of co-operative federalism is a necessity.

\footnotetext{
See id., art. 109; see also art. 198.

35 See Mahendra Prasad Singh, 'The Decline of the Indian Parliament' (2015) 14(3) India Rev. 352.

36 Pritam Baruah and Nicolas M. Rouleau, 'Democracy, Representation, and Self-Rule in the Indian Constitution' (2011) 44(2) Law \& Pol. Afr., Asia \& Latin Am. 177, 192.

37 Id. at 193.

38 Singh (n 35) 356.

39 Id. at 357.

40 Party Position in the Rajya Sabha, Parliament of India: Rajya Sabha, http://164 .100.47.5/Newmembers/partypositionsummary.aspx (accessed 20 November 2018).
} 
We can draw a few observations from this comparison. In terms of constitutional design, Italy started out as bicameral and unitary (then turned into a regional state), whereas India was bicameral and federal. In political reality, however, the Congress Party dominance in the Parliament and in state assemblies implied that the Indian Parliament was formally bicameral, but functionally closer to a unicameral system. In Italy, in addition to the conferral of equal powers, the features of the party system and the actual functioning of the electoral system made the two chambers similar and limited the added value of the bicameral arrangement. In both jurisdictions, then, we observe a shift from unicameralism to actual bicameralism. In Italy, the shift from 'disguised unicameralism'41 to bicameralism, started as a consequence of the overturn of the political system and the new electoral legislation in the 1990s, is likely to take place through the formal amendment process, ${ }^{42}$ if it ever happens. In India, the shift from de facto unicameralism to bicameralism has already taken place through informal means, principally in the diffusion of political power in the states.

In both jurisdictions, the reflective or deliberative functions of the second chamber have been sidelined in favor of regional representation (although in Italy this has remained only an aspiration). Members of the second chamber in both Italy and India are overwhelmingly career politicians. Many academic studies in India have found that legislative skills and technical competence are no longer serious factors that are considered in selecting candidates for appointment to the Rajya Sabha. ${ }^{43}$ In terms of regional representation, concerns have been expressed in Italy and also in India that the second houses actually represent what Barbara Guastaferro describes in her chapter as 'territorial institutions' rather than territorial interests. This is exemplified by the amendment to the electoral law in India, which decoupled Rajya Sabha membership for domiciliary requirements. ${ }^{44}$ The Italian constitutional reform

41 Arend Lijphart, Patterns of Democracy (Yale University Press 1999) 212; and George Tsebelis, 'Decision Making in Political Systems: Veto Players in Presidentialism, Parliamentarism, Multicameralism and Multipartyism' (1995) 25(3) British Journal of Political Science 289, 316.

42 Antonia Baraggia, 'The Italian Senate Under Reform: From Disguised Unicameralism to a True Regional Second Chamber?', Int'l J. Const. L. Blog, 16 July 2014, http://www.iconnectblog.com/2014/07/the-italian-senate-under-reform-from -disguised-unicameralism-to-a-true-regional-second-chamber (accessed 20 November 2018).

43 Abdul Gafoor Noorani, 'Rajya Sabha: Clog or Rubber Stamp?', in Abdul Gafoor Noorani (ed), Constitutional Questions in India. The President, Parliament and the States (OUP 2002); and Amirante (n 29) 89.

44 See also the decision of the Supreme Court of India in Kuldip Nayar v. Union of India \& Ors (2006) 7 SCC 1. Kuldip Nayar, 'Who belongs to the House, Who Doesn't', 
of 2016, however, would have offered a creative solution to this problem. The reform provided that senators would be elected in accordance 'with the choices expressed by the electors in voting for the renewal of regional Councils' ${ }^{45}$ This would have made citizens better informed during regional elections about which candidates running for regional councilor would also become members of the Senate. The votes of citizens would therefore take the effect of 'double-votes' - one for each office.

The experiences in Italy and India also demonstrate that it is a false dichotomy to frame the bicameralism discourse as a battle between democracy and wisdom, or as between democracy and minority rights. Bicameralism is not simply a method of taming popular sovereignty. In fact, if the function of the second chamber is considered to be the representation of regional interests, it may be a way of recognizing different forms of popular sovereignty. Bicameralism offers a way of combining temporally transient democracy - represented by the limited-life first chamber-with temporally extended democracy, represented by a staggered second chamber. A regionally-representative second chamber could contribute to a multi-tiered democratic system in which people are represented in a multiplicity of ways, based on a diverse set of electoral rules. The comparison between Italy and India therefore gives us some fascinating glimpses into the development of bicameralism on its own terms, and also into the relationship between bicameralism and multi-tiered government systems.

The Indian Express, 19 May 2016, http://indianexpress.com/article/opinion/columns/ rajya-sabha-membership-supreme-court-who-belongs-to-the-house-who-doesnt $-2807591 /$ (accessed 20 November 2018), discusses changes to domicile requirement for Rajya Sabha.

45 Constitutional Amendment Bill, A.S. 1429-D, art. 2, aiming to amend Italian Constitution, art. 57. The prospective composition of the Senate, as envisaged by the Constitutional Amendment Bill, and the implementing legislation, has been generally described as one of the most controversial aspects of the reform. See George Tsebelis, 'Compromesso Astorico: The Role of the Senate after the Italian Constitutional Reform' (2017) 47(1) Italian Political Science Review 87; in Italian, see Enzo Balboni, Roberto Bin, Francesca Biondi, Beniamino Caravita, Paolo Caretti, Stefano Ceccanti, Pietro Ciarlo, Salvatore Curreri, Marilisa D’Amico, Tommaso Edoardo Frosini, Tania Groppi, Giovanni Guzzetta, Vincenzo Lippolis, Nicola Lupo, Andrea Morrone, Silvia Niccolai, Marco Olivetti, Cesare Pinelli, Giusto Puccini, Emanuele Rossi, Carmela Salazar, Sandro Staiano, Giovanni Tarli Barbieri, Diletta Tega, Giulio Enea Vigevani, 'Dieci domande sulla riforma costituzionale' (2016) 2 Quad. Cost. 219, 314-325. 


\section{CONTENT AND CONTEXT}

Comparative inquiries like these open our eyes to new diagnoses and possibly prescriptions for institutional design. Comparative inquiries may also point the way to answers to foundational questions for which we thought we might have had definitive answers, only to learn from other jurisdictions that our answers may not be the best ones. We aim in this volume to bring together the richness of comparisons to the study of bicameralism. This volume emerges from a symposium held at the LUISS Guido Carli-a symposium held with a view to collecting the papers presented in an informative, useful and unique volume oriented to the problems and possibilities raised by bicameralism and its reforms. The papers were the subject of intense debate at the symposium and have been revised since.

Our discussions at the symposium traced the institutional evolution of bicameralism from ancient Greece and Rome, to Medieval Europe and the emergence of the House of Lords in the fourteenth century, in the intellectual debates triggered by the French Revolution and the design of the United States Constitution, to the reflections in Alexis de Tocqueville's Souvenirs, through to the present day. We observed that bicameralism is today a common feature of constitutional democracy, that at its best bicameralism diversifies democratic representation, strengthens representative government, promotes legislative deliberation, and reinforces the separation of powers, but that it has often failed either to fulfill its intended purposes or to keep pace with the evolution of constitutional democracy. Our discussions at the symposium also shone a light on constitutional states around the world, including Canada, Ireland, Romania and the United Kingdom, that have sought to revise their bicameral arrangements only to confront significant legal or political barriers to change. When faced with the reality that only relatively few reforms have succeeded, we inquired why. Drawing from country-specific and cross-national experiences with bicameralism, scholars in the symposium brought to bear comparative, historical, legal and theoretical perspectives to the study of constitutional reform of national legislatures. Indeed, the vital tension between bicameralism and constitutional reform, the way this complex relationship is and could be accommodated - often downgrading the level at which the reform is carried out, through changes in legislation and rules of procedure, wherever possible - is at the very center of this volume and constitutes the fil rouge that runs through the chapters.

We spent considerable time on some of the most important questions in constitutionalism. How should a legislature be structured, and what valuesdemocracy, representation, efficiency, deliberation-should its design prioritize? Does bicameralism still fit the times in light of the globalization and 
Europeanization of public policies, the increasing dominance of judicial and executive actors, mounting calls for greater devolution of legislative powers to subnational levels of government, and the multiplication of levels of government? When and under what conditions is a bicameral arrangement to be preferred over a unicameral one? How can second chambers be reformed to best perform their functions?

We have designed this volume to bring scholars into conversation around big ideas about bicameralism and the challenges surrounding its reform. This collection consists of three Parts, each an exploration into a different dimension of bicameralism, and it is opened with a Foreword by Meg Russell. Each Part features three to five contributions followed by a critical commentary by a scholar in the field. Commentaries situate the contributions, critique them, and identify their common themes with a view to pointing the way forward for future study into the forms, functions, limits and innovations in bicameralism. Part I is entitled 'Theories and challenges to bicameralism: multi-tiered government systems and the EU' and features five main contributions all meant to assess how bicameralism works in the presence of multiple levels of representation, in relation to the European integration process, and how reforms of bicameralism, if any, have responded to these challenges. Indeed, the EU exerts a significant pressure over the Member States' institutional systems and bicameralism is not exempted from that.

In Chapter 2, 'Bicameralism. Multiple theoretical roots in diverging practices', Maria Romaniello argues that there is currently no one model of bicameralism nor any single universally accepted criterion for justifying it. Diversity, she observes, has been the rule both in theory and in practice. Her chapter investigates the rationales of bicameralism, examines the different justifications developed in the literature through time and in different constitutional settlements, and ultimately highlights the impracticability of developing a unifying theory of bicameralism. Rather, she concludes, national bicameral arrangements continue to be driven by their own indigenous cultural and political factors.

In Chapter 3, "Visible" and "invisible" second chambers in unitary states. "Territorialising" national legislatures in Italy and the United Kingdom', Barbara Guastaferro analyses reforms of constitutional significance that have recently affected the design and functioning of bicameralism in Italy and the United Kingdom as multi-tiered government systems. In both cases, those reforms modified - or attempted to modify - the composition of national parliaments by creating or bolstering territorial representation, and responding to a call for territorial differentiation in one of the Houses of Parliament. She first discusses the content of the reforms and then explores the constitutional and political significance of territorial representation for unitary, rather than federal states, as well as its uncertain paths. 
In Chapter 4, 'How does the European Union challenge Bicameralism? Lessons from the Italian case', Pietro Faraguna begins from the assumption that all modern bicameral systems are based on two possible ultimate justifications: the separation of powers and the protection of minorities. He explores the model of bicameralism adopted in the Italian Constitution of 1947, almost exclusively shaped, according to the author, by the aim to enforce separation of powers as the only driver originally considered. This pattern, however, has become increasingly outdated in light of the European integration process, a key factor of the overcoming of the main justification of Italian bicameralism, as shown by the last attempt of constitutional reform.

In Chapter 5, 'The scrutiny of EU documents in bicameral systems: opportunity or weakness?', Wouter Wolfs and Caterina Cigala analyse 13 bicameral parliaments in the EU with the objective of evaluating the extent to which cooperation exists between both chambers when they deal with European affairs. Their classification of cooperation between the two chambers positions the bicameral parliaments along a continuum ranging from no interaction to full interaction, and it categorizes them into one of four types: collaborators, coordinators, communicators, and no interaction.

In Chapter 6, 'The House of Lords faces up to Brexit', Peter Leyland investigates the role played by the UK House of Lords - a unique second chamber in comparative perspective - in the controversial process of withdrawal from the EU. He argues that in passing Brexit legislation and in the scrutiny of governmental action through the relevant select committees the House of Lords provides significant resistance to the House of Commons, which tends to be dominated by the executive. However, it is contended that this Upper House ultimately lacks both democratic legitimacy and the formal power to fundamentally influence the policies adopted by government.

Part I concludes with a commentary provided by Patricia Popelier, 'Bicameralism in multi-tiered systems'. She explores the complexity of bicameral arrangements in multi-tiered systems of governance, the limits of and the alternatives to territorial representation and what the role of the EU is in shaping bicameralism today.

Part II features three contributions on the theme of "Challenging Unicameralism'. In Chapter 8, 'The shadow of bicameralism in a unicameral state: dispersed functional bicameralism in Bulgaria?', Mihail Vatsov and Polina Vakleva propose the notion of 'functional bicameralism'. They illustrate this idea with reference to Bulgaria, a formally unicameral state where other institutions have historically served the functions and values of bicameralism.

In Chapter 9, 'Defending bicameralism and equalising powers: the case of Peru', Diego Serra focuses on two main issues: to what extent should unicameralism limit the expanded powers of the executive; and to what extent should 
bicameralism be regarded as a more suitable means for equalizing powers? His chapter focuses on Peru, whose senate was abolished in 1992. The Peruvian Constitution allocated some of the former Senate's powers to a Permanent Commission. Originally empowered to replace the Congress during parliamentary recess, today this Commission has become far more powerful and influential. The result may well be a unicameral system more in name than reality.

David Kenny brings us to Ireland, to both its past and future, where the Seanad has recently confronted - and in a failed referendum, has survivedthe possibility of abolition. In Chapter 10, 'The failed referendum to abolish the Ireland's Senate: rejecting unicameralism in a small and relatively homogenous country', Kenny outlines the unusual history and composition of Seanad, as well as its limited powers and uses. Kenny explains that it was created with some reluctance, given little power, and immediately lost any distinctive characteristics that it might have had due to party politics. This 'masked unicameralism' has played a role during the referendum campaign in order to keep the upper house in existence.

Part II concludes with critical commentary by Cristina Fasone, 'Unicameralism and "masked" bicameralism'. She elaborates on the main chapters and tries to identify the conditions under which a second chamber can be deemed in existence as well as the pros and cons of having a functional bicameralism or second chambers 'lookalike' in place.

Part III of this volume collects four contributions under the theme 'Reforming or abolishing the upper house?'. Chapter 12, The 'Sénat Français of the Fifth Republic: the permanent paradox', by Priscilla Jensel Monge, probes the paradox between the many praises and criticisms of the French Senate. It is an institution that, she argues, has frequently been portrayed as a 'political anomaly'. Monge argues against the many criticisms directed at the Senate, seeking to demonstrate it occupies an essential role in the distinctive institutional configuration of the Fifth Republic, and that a profound reform of this institution appears neither possible nor indeed desirable. In Chapter 13, 'The future of Poland's second chamber: is the Senate still needed?', Katarzyna Granat explores the bicameral system of the Polish Parliament and discusses possible reforms of its election procedures and functions in light of the experience in other bicameral systems. Granat suggests reforms that, in her view, could create a stronger bicameral system with more symmetrical powers but less congruent chambers. Nonetheless, she questions whether Senate reform is indeed possible.

In Chapter 14, 'Reshaping the National Council of the Republic of Slovenia?, Dušan Štrus discusses the National Council, the upper house of the Slovenian Parliament, established in 1991 as a compromise based on the structure of the Bavarian Senate. Endowed with modest but nonetheless important powers, the 
National Council has long been the subject of possible reform or abolishment. Štrus outlines the proposals and main reasons driving them. He then evaluates their strengths and weaknesses - as well as those of the Slovenian bicameral structure itself - in comparative perspective.

Chapter 15, 'Bicameralism(s) in the age of ethnicity: prospects for reform of legislatures in Bosnia and Herzegovina', by Nedim Kulenović, argues that the judgments of the European Court of Human Rights, holding the arrangements of the House of People of the Bosnian Parliament to be unequal, call for a serious reexamination of the current power-sharing institutional solutions in Bosnia and Herzegovina. By analysing the features of second houses of parliament across different levels of government, Kulenović scrutinizes the nature of the Bosnian consociational federation and contemplates models for reforming bicameralism. He goes on to consider the role that a reformed second chamber could play in remedying the failings of current consociational arrangements.

In Chapter 16, 'Bicameralism as a normative choice in the tension between its reform and its passing', Giovanni Piccirilli closes Part III with critical and constructive reflections on the preceding four chapters, dealing with bicameralism as a normative choice and with the lessons we can draw from the systematic failure of radical reforms affecting upper houses.

\section{IN MEMORIAM}

The questions that run across the chapters were of great interest to Gabriella Angiulli, a dear friend and colleague to whom the Symposium-organised thanks to the generosity and support of Carmela Decaro, Nicola Lupo and Lorenza Violini and held at LUISS Guido Carli Department of Political Science on 2-3 May 2016 - and this entire collection are dedicated. At the time, she was a doctoral student at the University of Siena and a teaching assistant at LUISS Guido Carli, where she earned her master's degree cum laude in Comparative Public Law in 2008 under the supervision of Carmela Decaro. This project on bicameralism was inspired by her interest in the subject; indeed, she devoted her master's dissertation to the study of the Senate of Canada in comparative perspective. She left this world as she was embarking on her promising academic career. This volume and the questions it brings to light, some of which are answered and others left open as perennially unanswerable problems, honor her memory. It is our hope that this volume becomes a useful resource for scholars interested in the design, history, politics, and theory of bicameralism in comparative perspective. 